\title{
Glutamate-Induced Efflux of Protein, Neuron-Specific Enolase and Lactate Dehydrogenase from a Mesencephalic Cell Culture ${ }^{1}$ )
}

\author{
Johann Gross ${ }^{1}$, Ute Ungethüm ${ }^{1}$, Nadejda Andreeva ${ }^{2}$, Julia Heldt ${ }^{1}$, Friedrich Priem ${ }^{1}$, Grit Marschhausen ${ }^{1}$ and \\ Thomas Altmann ${ }^{1}$ \\ ${ }^{1}$ Institut für Pathologische und Klinische Biochemie, Universitätsklinikum Charité, Humboldt-Universität zu \\ Berlin, Berlin, Germany \\ 2 Brain Research Institute, Academy of Medical Sciences, Moscow, Russia
}

Summary: A mixed mesencephalic cell culture damaged by glutamate was used as a model to study the efflux of lactate dehydrogenase and neuron-specific enolase from neuronal cells into the culture medium. Glutamate toxicity was induced in sister cultures by $15 \mathrm{~min}$ exposure to $100 \mu \mathrm{mol} / 1$ glutamate in a $\mathrm{Ca}^{2+}$ containing salt solution. Cell injury was monitored $24 \mathrm{~h}$ later by measuring the lactate dehydrogenase activity and the neuron-specific enolase content in the cells and in the culture medium.

The neuronal cell damage is reflected by an efflux of neuron-specific enolase and lactate dehydrogenase from the cells and an increase of lactate dehydrogenase catalytic activity concentration and neuron-specific enolase mass concentration in the culture medium. It was found that the efflux fraction calculated from estimations of the cells was clearly higher than the efflux fraction calculated from estimations of the amount of enzymes found in the culture medium. Calculations of the recovery of lactate dehydrogenase and neuron-specific enolase and experiments designed to study the efflux of lactate dehydrogenase and neuron-specific enolase during incubation and washing showed that higher amounts of neuron-specific enolase are released than lactate dehydrogenase.

A close correlation was found between the glutamate-induced changes of the neuron-specific enolase efflux fraction, based on enzyme determinations of the cells, and the change of the microscopically counted neuron-specific enolase immunoreactive cell numbers. This indicates that the determination of the neuron-specific enolase efflux fraction (cells) is an accurate and sensitive marker of damaged neurons. The lactate dehydrogenase efflux fraction seems to be less sensitive for the quantitation of neuronal cell damage; in addition, it depends not only on the neuronal damage but also on the proportion of neurons in the cell culture.

\section{Introduction}

Determinations of lactate dehydrogenase ${ }^{2}$ ) and neuronspecific enolase ${ }^{2}$ ) in body fluids are frequently used in the biochemical diagnostics. Both proteins are glycolytic enzymes, are localised in the cytoplasm, and have similar relative molecular masses (1). Lactate dehydrogenase is present in all cell types, whereas neuron-specific enolase occurs mainly in mature neuronal cells and in neuroendocrine tissue. In the brain tissue neuron-specific enolase is localised in neurons only. Because of its localisation neuron-specific enolase is used in the diagnosis of acute brain damage and tumours of neuroendo-

\footnotetext{
$\left.{ }^{1}\right)$ Funding organizations:

Deutsche Forschungsgemeinschaft (Gr. 1256/2-1),

Universitätsklinikum Charité (N93-077)

2) Enzymes:

Lactate dehydrogenase ( $L$-Lactate $: \mathrm{NAD}^{+}$oxidoreductase, $\mathrm{EC}$

1.1.1.27);

Enolase (Phosphopyruvate hydratase, EC 4.2.1.11)
}

crine origin $(2,3)$. Furthermore, neuron-specific enolase is also used as a marker of neuronal differentiation $(4,5)$.

The quantitation of neuronal cell death is an important objective in many experimental and clinical studies. Methods determining cell death use different principles: the exclusion of vital dyes like trypan blue, the release of radioactive isotopes from prelabelled cells or the measurement of cytoplasmic enzyme activity released by damaged cells (6). The most widely used measure of cell injury in culture is the estimation of lactate dehydrogenase release into the culture medium (7).

In the present study a mixed mesencephalic cell culture damaged by glutamate was used as a model to study the efflux of lactate dehydrogenase and neuron-specific enolase from neuronal cells (8). This model is characterised by the following features.

(i) The glutamate-induced cell damage is neuron-specific; it is well known that overstimulation of glutamate 
receptors induces acute and/or delayed neuronal death $(9,10)$.

(ii) The number of damaged neurons may be estimated by counting the neuron-specific enolase immunoreactive cells before and after the cell injury (11).

(iii) Due to the closed character of the cell culture system, it is possible to estimate the distribution of the enzymes between the extra- and intra-cellular space and to calculate the recovery rate, i. e. the amount of enzyme released from the damaged cells and appearing in the medium.

The purpose of this investigation was to experimentally determine the value of neuron-specific enolase, a neuron-specific cytoplasmic enzyme and of lactate dehydrogenase, a ubiquitous cytoplasmic enzyme, for the quantitation of neuronal cell damage.

\section{Materials and Methods}

Pregnant Wistar rats were obtained from the Bundesgesundheitsamt (Berlin). Foetal calf serum, DMEM/Ham's F12 nutrient mixture and trypsin/EDTA mixture were purchased from Gibco Laboratories (Life Technologies $\mathrm{GmBH}$, Eggenstein, Germany), glutamine, human transferrin, putrescine, insulin, poly- $L$-lysine $\left(M_{\mathrm{r}}\right.$ $70000-150000$ ), glutamic acid and $D L$-2-amino-5-phosphonovalerate were from Sigma (Deisenhofen, Germany), 48-well cluster plates were from Costar Tecnomara (Bodenheim, Germany); neuron-specific enolase test kits were obtained from BYK-Sangtec Diagnostica (Germany) and lactate dehydrogenase test kits from Boehringer (Mannheim, Germany).

\section{Preparation of the cultures}

Ventral mesencephalic regions prepared from foetuses on the 14th gestational day under the stereomicroscope were collected into glucose-supplemented phosphate-buffered saline (concentrations in mmol/l: $\mathrm{NaCl} 116, \mathrm{Na}_{2} \mathrm{HPO}_{4}$ 27.2, $\mathrm{KH}_{2} \mathrm{PO}_{4} 6.1$, glucose 11, $\mathrm{pH}$ $=7.2$ ). After mild trypsinisation $\left(15 \mathrm{~min}\right.$ at $37^{\circ} \mathrm{C}$ in $0.5 \mathrm{~g} / 1$ trypsin and $0.2 \mathrm{~g} / \mathrm{l}$ EDTA dissolved in glucose-supplemented phosphatebuffered saline) the tissue fragments were washed twice with glucose-supplemented phosphate-buffered saline supplemented with foetal calf serum, volume fraction 0.05 and subjected to repeated pipetting in the cultural medium, which consisted of DMEM/ Ham's F12 nutrient mixture, volume fraction 0.9 and foetal calf serum, volume fraction 0.1 . This cultural medium was supplemented with $2 \mathrm{mmol} / \mathrm{l}$ glutamine, $1.25 \mu \mathrm{mol} / \mathrm{l}$ transferrin, $60 \mu \mathrm{mol} / \mathrm{l}$ putrescine, $10^{5} \mathrm{U} / 1$ penicillin, $100 \mathrm{mg} / \mathrm{l}$ streptomycin, $5 \mathrm{mmol} / \mathrm{l}$ HEPES and $3 \mathrm{~g} / \mathrm{l}$ glucose. The cell suspension was centrifuged for $10 \mathrm{~min}$ at $20^{\circ} \mathrm{C}$ and $180 \mathrm{~g}\left(r_{\mathrm{av}}=13.2 \mathrm{~cm}\right)$ and the cells were resuspended in the required volume of the medium to achieve a final cell concentration of $10^{9} / 1$. The suspension was then applied to poly- $L$-lysine coated 48 -well cluster plates at a plating density of 250000 cells/well $\left(=1 \mathrm{~cm}^{2}\right)$ in $250 \mu \mathrm{l}$ of medium. Cytosine arabinoside $(10 \mu \mathrm{g})$ was added to all the cultures on the 6th day in vitro to inhibit proliferation of non-neuronal cells. No further medium change was performed. Cells were grown in media containing $4.2 \mathrm{mmol} / / \mathrm{K}^{+}$and $24.2 \mathrm{mmol} / \mathrm{K} \mathrm{K}^{+}$.

\section{Treatment with glutamate}

Culture medium was removed from culture wells by aspiration and the monolayers were washed once with $\mathrm{Ca}^{2+}$-containing saline of

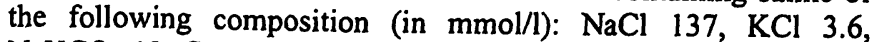
$\mathrm{NaHCO}_{3} 12, \mathrm{CaCl}_{2}$ 2.3, $\mathrm{MgCl}_{2}$ 1.0, Glucose 11, pH 7.5-7.6. Glutamate toxicity was induced in sister cultures by $15 \mathrm{~min}$ exposure of the cultures to $100 \mu \mathrm{mol} / \mathrm{l}$ glutamate in the same solution. There- after the cultures were washed once with $\mathrm{Ca}^{2+}$-containing saline and the medium was returned. After $24 \mathrm{~h}$ the medium and the cells were collected for neuron-specific enolase and lactate dehydrogenase determination. The cells were scraped off into $250 \mu$ l buffered saline glucose-solution and homogenised using a Potter homogeniser. Protein, lactate dehydrogenase and neuron-specific enolase were determined in the homogenate.

Immunostaining

Identification of neuron-specific enolase immunoreactive cells was carried out by universal LSAB-Kit, No. K 680, (Dako Diagnostika $\mathrm{GmbH}$, Hamburg, Germany) using a rabbit anti-human neuron-specific enolase antibody (Dako). The number of neuron-specific enolase immunoreactive cells were counted in 9 visual fields per well.

Determination of protein and neuron-specific enolase and lactate dehydrogenase

Neuronal cell injury was quantified by measuring the enzymes and protein in cells and the enzymes in the supernatant. The neuronspecific enolase was determined by the immunoluminometric assay (BYK SANGTEC DIAGNOSTICA, Dietzenbach, Germany) and lactate dehydrogenase was measured using a continuous enzyme assay (Boehringer, Mannheim, Hitachi 747). The concentrations of protein were estimated according to Lowry et al. (12) using bovine serum albumin as standard.

\section{Calculations}

Enzyme or protein (analyte) efflux fraction as an indicator of cell injury was calculated from the content per well by the following formula:

$$
\begin{aligned}
& \text { Efflux }_{\text {cells }}=\frac{\left(\text { analyte }_{\text {control cells }}-\text { analyte }_{\text {glu cells }}\right)}{\text { analyte }_{\text {control cells }}} \\
& \text { Efflux }_{\text {medium }}=\frac{\left(\text { analyte }_{\text {glu medium }}-\text { analyte }_{\text {control medium }}\right)}{\text { analyte }_{\text {control cells }}}
\end{aligned}
$$

The recovery fraction (amount of neuron-specific enolase or lactate dehydrogenase appearing in the medium and compared with the amount of neuron-specific enolase or lactate dehydrogenase released from the cells) was calculated by the following formula:

$$
\text { Recovery fraction }=\frac{\left(\text { analyte }_{\text {glu medium }}-\text { analyte }_{\text {control medium }}\right)}{\left(\text { analyte }_{\text {control cells }}-\text { analyte }_{\text {glu cells }}\right)}
$$

where

analyte $_{\text {control cells }}=$ analyte content in the cells without glutamate addition

analyte glu cells $=$ analyte content in the cells with glutamate addition

analyte $_{\text {glu medium }}=$ analyte content in the medium with glutamate addition

analyte $_{\text {control medium }}=$ analyte content in the medium without glutamate addition

\section{Statistical analysis}

Significance of multiple group differences was estimated using ANOVA, Duncan or Tukey HSD test (Statistica, Microsoft). For two group comparisons the Mann-Whitney U-test was used. Means \pm SEM are shown in the figures.

\section{Results}

Developmental changes of protein, lactate dehydrogenase and neuron-specific enolase in the mesencephalic cell culture

Figure 1 shows the developmental changes in protein content, lactate dehydrogenase activity and neuron-spe- 


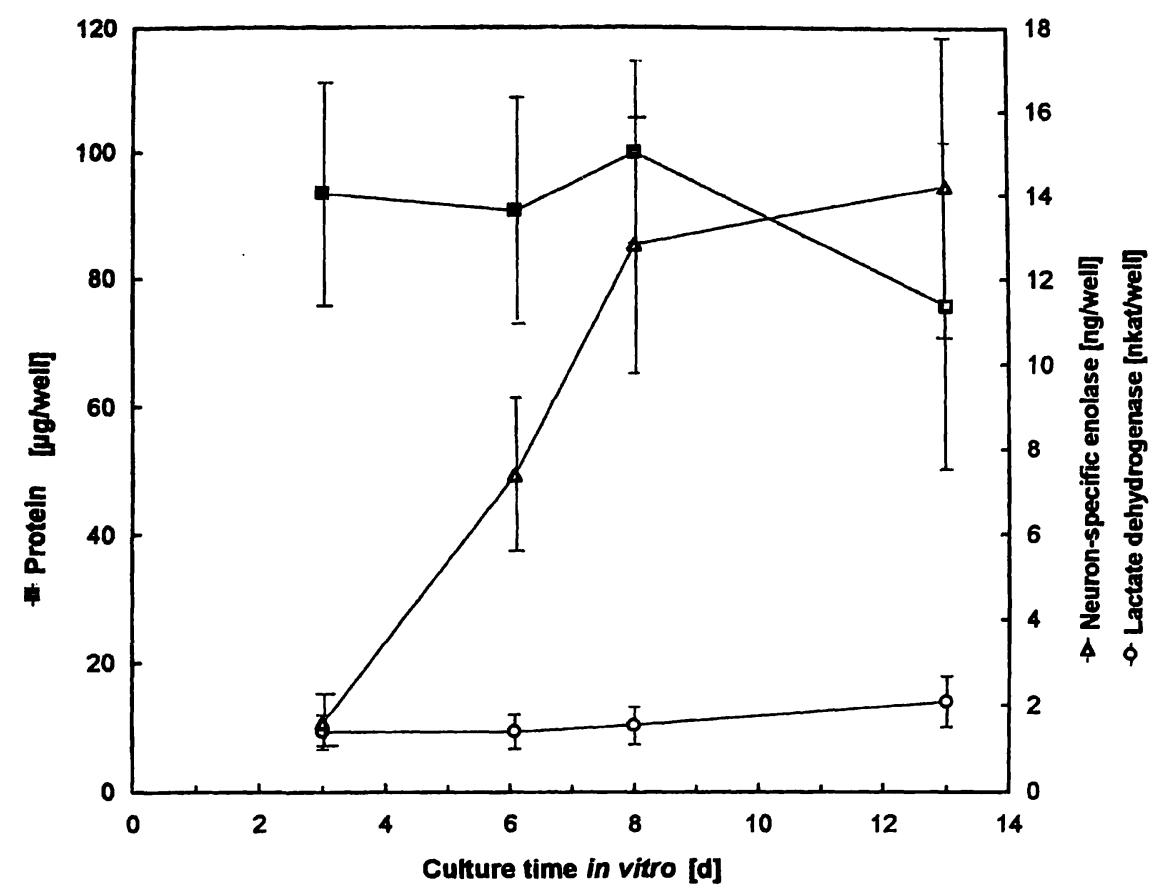

Fig. 1 Changes in protein content, lactate dehydrogenase catalytic activity concentration and neuron-specific enolase mass concentration in the cell monolayer during culture. Data from 6 or 4 (8th day in vitro) different cell culture preparations.

cific enolase level in the cell monolayer. The protein content and the lactate dehydrogenase activity remain relatively constant up to the 14 th day in vitro. In contrast, there is a continuous increase in the neuron-specific enolase content from the 3rd to the 13th day in vitro as expression of the differentiation and maturation of cells. Since cells grown in the medium containing $4.2 \mathrm{mmol} / 1 \mathrm{~K}^{+}$or $24.2 \mathrm{mmol} / 1 \mathrm{~K}^{+}$did not show any differences, the data were combined.

\section{Efflux of protein, lactate dehydrogenase and neuron-specific enolase \\ from damaged neurons}

The efflux of lactate dehydrogenase and neuron-specific enolase from mesencephalic cells induced by glutamate was analysed separately by analysis of the cells, and by analysis of the medium. In the cells the damage is reflected by a decrease of protein, neuron-specific enolase and lactate dehydrogenase. The efflux fractions of lactate dehydrogenase and neuron-specific enolase correlate with the efflux fraction of protein (data not shown). The efflux of lactate dehydrogenase and neuron-specific enolase in the medium is reflected by a significant increase in the level of lactate dehydrogenase catalytic activity concentration and neuron-specific enolase mass concentration beyond the 8th day in vitro (fig. 2). Cultures grown in a medium containing $24.2 \mathrm{mmol} / 1 \mathrm{~K}^{+}$ show higher values of both enzymes after glutamate injury than cells grown in $4.2 \mathrm{mmol} / 1 \mathrm{~K}^{+}$. As expected, there was a significant correlation between the efflux fraction calculated from the cells and that calculated from determinations in the culture media:

$$
\begin{aligned}
& \text { LDH-efflux fraction } \\
& =-11.4+1.55 \mathrm{LDH}_{\text {cells) }} \\
& \mathrm{r}=0.52, \mathrm{p}<0.01, \mathrm{n}=32 \\
& \text { NSE-efflux-fraction }_{\text {(medium); }} \\
& =18.2+1.95 \mathrm{NSE}_{\text {(cells) }} \\
& \mathrm{r}=0.6, \mathrm{p}<0.01, \mathrm{n}=32
\end{aligned}
$$

It is interesting to note that the neuron-specific enolase efflux estimated from the cells is clearly higher than the efflux calculated from the media. This observation suggested differences in the recovery of the enzymes released from the cells and appearing in the medium. Calculation of the recovery showed lower values for neuron-specific enolase $(32.7 \pm 35.1 \%)$ than for lactate dehydrogenase $(68.1 \pm 32.4 \%),(p<0.0001)$. It was concluded that there is a loss of neuron-specific enolase either during handling of the cells during washing and incubation, or by degradation in the culture during the $24 \mathrm{~h}$ period following glutamate exposure. Calculations of the neuron-specific enolase/lactate dehydrogenase ratio of the control cells, the glutamate-treated cells, and in the medium supported this assumption. Selective neuronal cell death would lead to a lower neuron-specific enolase/lactate dehydrogenase ratio in damaged cells and a higher ratio in the released cell contents. In fact, a lower ratio was found in glutamate-treated cells, but an unchanged or decreased neuron-specific enolase/ lactate dehydrogenase ratio was found in the medium (data not shown).

Experiments designed to study the efflux of neuron-specific enolase and lactate dehydrogenase during incubation and washing showed that the release of neuron-spe- 

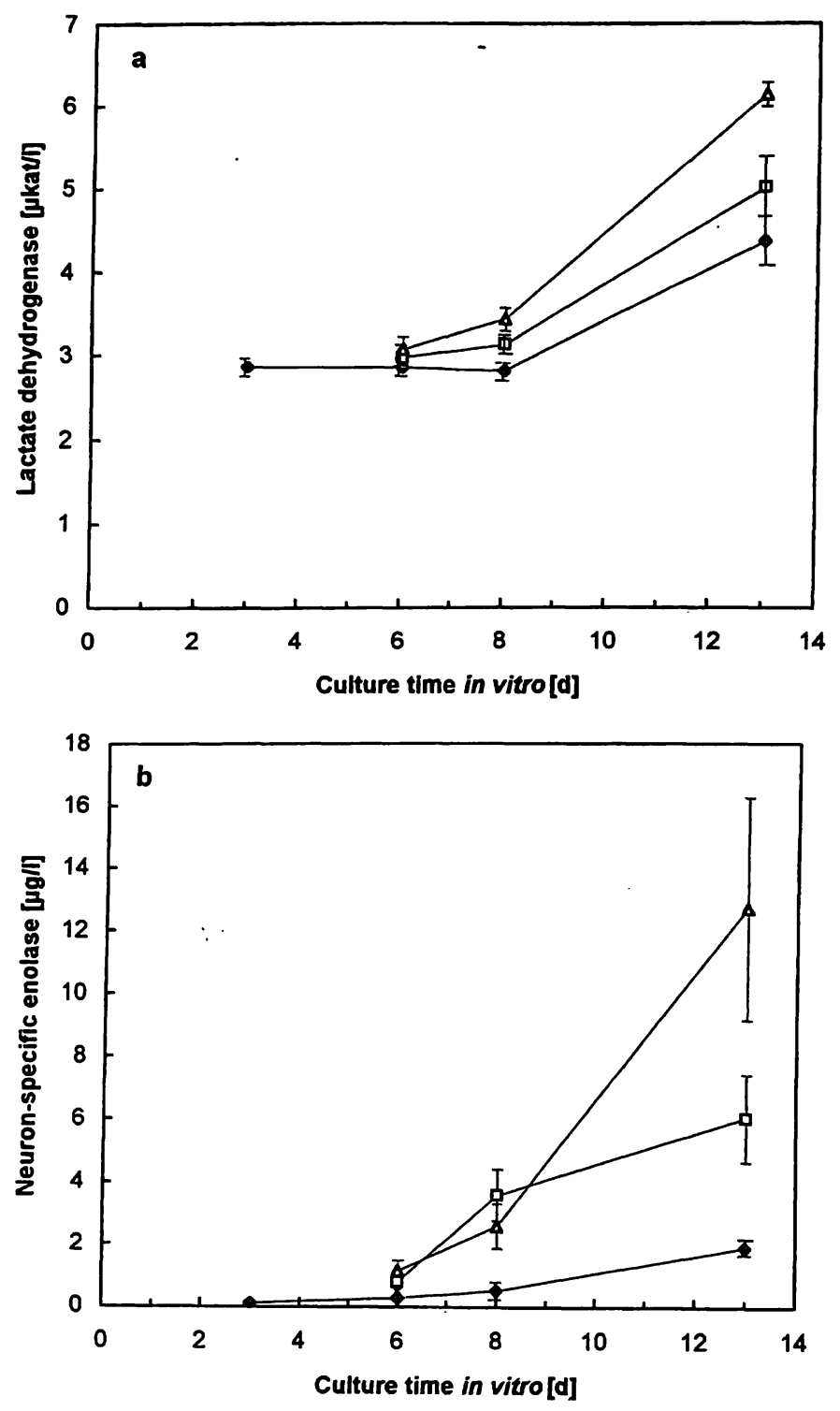

Fig. 2 Changes of lactate dehydrogenase catalytic activity concentration (a) and neuron-specific enolase mass concentration (b) in the medium in control and glutamate-treated cell culture. Cells grown in medium containing $4.2 \mathrm{mmol} / 1 \mathrm{~K}^{+}(\square)$ and $24.2 \mathrm{mmol} / \mathrm{l}$ $\mathrm{K}^{+}(\Delta)$ were exposed to $100 \mu \mathrm{mol} / \mathrm{l}$ glutamate for $15 \mathrm{~min}$. Twentyfour hours later the level of both quantities was determined. The wash and incubation solutions were discarded.

Data of control cells $(\Delta)$ were combined (no difference).

Differences between control and glutamate experiments significant at $\mathrm{p}<0.05$ on day 6 (neuron-specific enolase), day 8 (neuronspecific enolase) and day 13 (neuron-specific enolase and lactate dehydrogenase); $n=6$ (day 6 and 13 ), $n=4$ (day 8 ).

cific enolase is clearly greater than that of lactate dehydrogenase (tab. 1).

Correlations between the number of damaged neuron-specific enolase immunoreactive cells and the neuron-specific enolase and lactate dehydrogenase efflux

Neurons were stained with anti-neuron-specific enolase and counted in some experiments in order to verify the quantitative relations between the neuronal damage induced by glutamate and the efflux fraction of lactate dehydrogenase and neuron-specific enolase of the cell
Tab. 1 Efflux of lactate dehydrogenase and neuron-specific enolase from mesencephalic cell culture during washing and incubation

\begin{tabular}{|c|c|c|}
\hline & $\begin{array}{l}\text { Lactate } \\
\text { dehydrogenase }\end{array}$ & $\begin{array}{l}\text { Neuron- } \\
\text { specific } \\
\text { enolase }\end{array}$ \\
\hline $\begin{array}{l}\text { Enzyme in control cells } \\
\text { Efflux fraction } \\
\text { washills) during } \\
\text { wash and incubation }\end{array}$ & $7.0 \pm 2.0^{\circ} \mu \mathrm{kat} / \mathrm{l}$ & $48.3 \pm 5.2 \mu \mathrm{g} / \mathrm{l}$ \\
\hline $\begin{array}{l}\mathrm{Ca}^{2+} \text { containing } \\
\text { saline* }\end{array}$ & $1.3 \pm 0.9 \%$ & $7.1 \pm 1.9^{\mathrm{a}} \%$ \\
\hline $\begin{array}{l}\mathrm{Ca}^{2+} \text { containing } \\
\text { saline }+ \text { glutamate* }\end{array}$ & $2.9 \pm 2.1 \%$ & $10.3 \pm 5.7^{\mathrm{a} o} \%$ \\
\hline
\end{tabular}

${ }^{\mathrm{a}} \mathrm{p}<0.0002$; Data from 5 different cell culture preparations between the 8th-12th day in vitro.

Procedure: $1 \mathrm{~min}$ washing, $15 \mathrm{~min}$ incubation and $1 \mathrm{~min}$ washing. The washing solutions were pooled.

* See Materials and Methods, section "Treatment with glutamate".

culture. There is a close correlation between the glutamate-induced changes in the neuron-specific enolase immunoreactive cell counts and cell injury calculated on the basis of the neuron-specific enolase efflux-fraction (cells, fig. 3). The observed data show that the lactate dehydrogenase efflux-fraction (cells) remained undetectable, despite changes in the number of neuron-specific enolase immunoreactive cells of up to $20 \%$.

\section{Discussion}

The mesencephalic cell culture model of glutamate toxicity appears to be useful for comparing diagnostic value of neuron-specific enolase (a neuron-specific enzyme) and lactate dehydrogenase (a ubiquitous enzyme) as indicators of neuronal cell damage. Our present results agree with data from the literature concerning general criteria of a mesencephalic cell culture, such as cell number, morphology, development of the cells (5). The culture used is a mixed culture containing neurons and glial cells. In parallel experiments $40.1 \%$ of cells were identified as neuronal cells on the 11th day in vitro using the method of neuron-specific enolase immunostaining (8). The continuous increase in neuron-specific enolase concentration in the cells during development reflects the neuronal differentiation and maturation (fig. 1); the increase in neuron-specific enolase and lactate dehydrogenase in the medium of control cultures may indicate spontaneous neuronal death of cells during development (fig. 2).

The mechanism of glutamate-induced cell damage is well known. Glutamate acts as an excitotoxin, inducing the influx of $\mathrm{Ca}^{2+}$ which triggers damage leading to the efflux of lactate dehydrogenase and neuron-specific enolase $(10,13)$. The higher efflux of lactate dehydrogenase and neuron-specific enolase in the cell culture grown in $24.2 \mathrm{mmol} / 1 \mathrm{~K}^{+}$in comparison with cells grown in $4.2 \mathrm{mmol} / 1 \mathrm{~K}^{+}$beyond the 8 th day in vitro is 


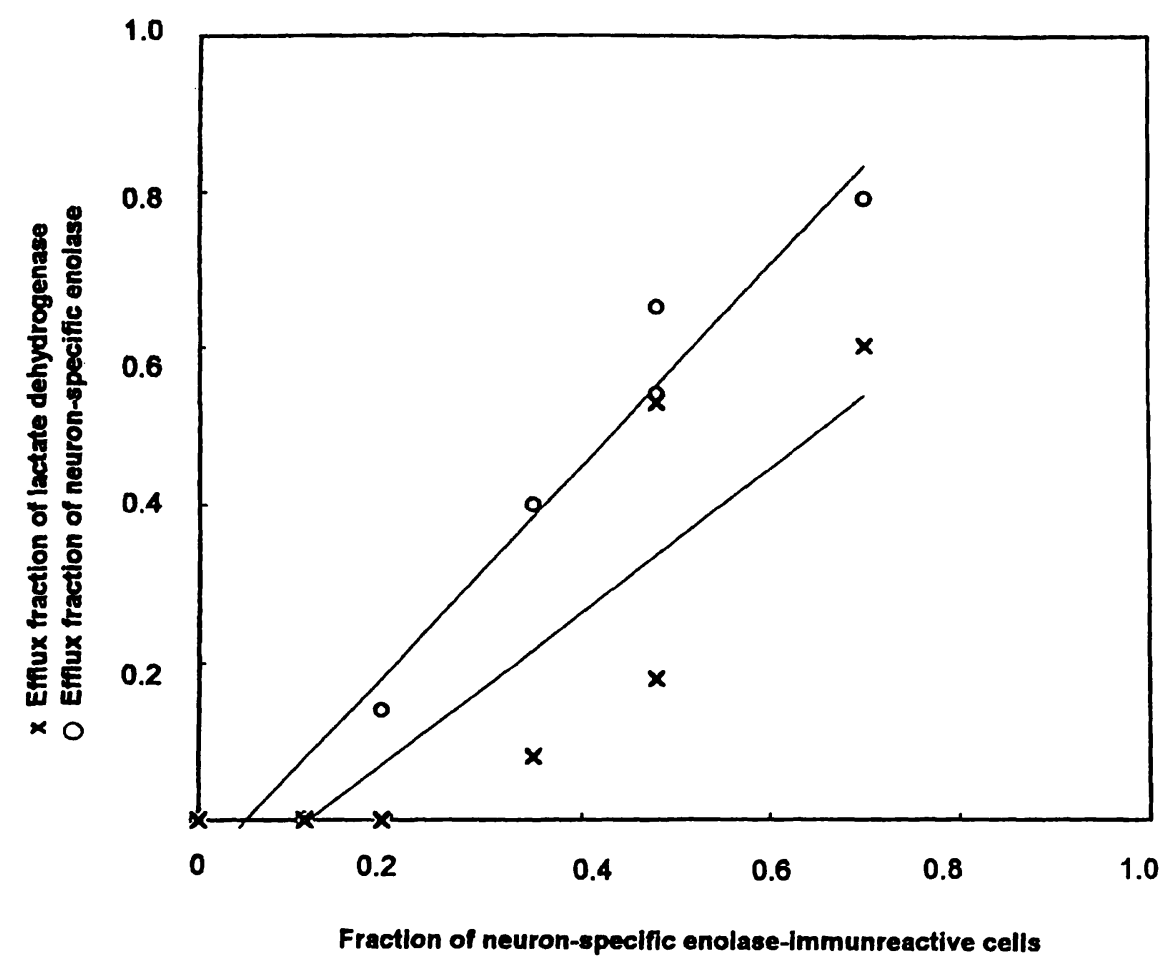

Fig. 3 Correlations between neuronal injury quantified by staining and counting neuron-specific enolase immunoreactive cells and by determination of neuron-specific enolase and lactate dehydrogenase efflux fraction. A linear regression model was assumed described by the equation for neuron-specific enolase (NSE, 0 ) and lactate dehydrogenase ( $\mathrm{LDH}, \mathrm{x})$ :

"NSE-efflux fraction (cells) $=-0.62+1.28 \times$ NSE-immunoreactive cells", $r=0.98$ and

most probably a reflection of the higher vulnerability of mature cells to glutamate, due to the expression of $\mathrm{N}$ methyl- $D$-aspartate receptors (8).

The efflux of cytoplasmic proteins from damaged cells depends in general on factors like molecular properties of the protein, intracellular localisation, the type of cell lesion and alterations of the cytoskeleton of the cell membrane (14). In spite of the similarities of lactate dehydrogenase and neuron-specific enolase with respect to molecular mass and their assumed intracellular localisation, there are obvious differences in the kinetics of their release. This assumption results from

(i) calculations of the recovery,

(ii) calculations of the neuron-specific enolase/lactate dehydrogenase ratio in damaged cells, control cells, and of the released cell contents,

(iii) the washing and incubation experiments shown in table 1 , and

(iv) failure to detect neuron-specific enolase release despite neuronal damage of up to $20 \%$ (fig. 3 ).

Differences in the stability of the released lactate dehydrogenase and neuron-specific enolase in the culture medium during $24 \mathrm{~h}$ at $37^{\circ} \mathrm{C}$ were not found. These data lead to the assumption that neuron-specific enolase is
"LDH-efflux fraction (cells) $=-0.10+0.92 \times$ NSE-immunoreactive cells"; $r=0.87$.

Data from 7 different preparations on the 8 th-12th day in vitro using 50,100 or $200 \mu \mathrm{mol} / /$ glutamate. Neuron-specific enolaseimmunoreactive cells were counted in 9 visual fields per well. Each value represents a mean of 3 wells counted (CV of counting $12.7 \%)$.

released with a higher rate than lactate dehydrogenase during treatment of the cells. A higher release rate of neuron-specific enolase in relation to lactate dehydrogenase has also been reported from thrombocytes during blood coagulation (15). The release of neuron-specific enolase by cell handling or mild injuries to the cells might be explained by a different intracellular localisation of neuron-specific enolase and lactate dehydrogenase within the neurons, the relationship of neuron-specific enolase to the synaptic plasma membranes (16), or the relationship of neuron-specific enolase to the cytoskeleton (17).

\section{Conclusions}

The following considerations and conclusions may be drawn from the results obtained in this study, concerning the quantitation of neuronal cell death based on the determination of lactate dehydrogenase and neuron-specific enolase in the cells and in the medium.

(i) The neuron-specific enolase efflux fraction, calculated from measurements performed on the cells, correlates highly significantly with the number of damaged neuronal cells. The relationship between the lactate dehydrogenase efflux fraction and damaged neuron-specific enolase-immunoreactive cells could also be de- 
scribed by a linear regression model with $p<0.01$, but from the experimental data of figure 3 , it is obvious that there is no detectable lactate dehydrogenase efflux when the damage to neuronal cells is low. This finding could be interpreted as a lower sensitivity of lactate dehydrogenase to neuronal cell damage. Theoretical considerations show that the neuron-specific enolase efflux fraction depends on the neuronal damage only, but that the lactate dehydrogenase efflux fraction depends in addition on the relative proportions of neuronal and nonneuronal cells. With $40 \%$ neuronal cells and neuronal damage of $10 \%$, the lactate dehydrogenase efflux fraction would be $4 \%$, i.e. within the methodical error of analytical determinations of the efflux fractions.

(ii) Estimations of the efflux fractions of the enzymes calculated from determinations in the culture medium depend strongly on the recovery of those enzymes, and cannot used directly for the quantitative evaluation of cell damage in a cell culture. Therefore a calibration curve is necessary (18). Our data show that lactate dehydrogenase and neuron-specific enolase are released during washing. This loss is clearly higher for neuron-specific enolase than for lactate dehydrógenase and explains the differences in the regression coefficients for the neuron-specific enolase and lactate dehydrogenase efflux fractions calculated from the determinations performed on the cells and the neuron-specific enolase or lactate dehydrogenase efflux fraction calculated from the medium. The present data support the conclusion of Juurlink \& Hertz (19) that caution must be used when using the lactate dehydrogenase technique for quantitation of neuronal cell damage.

\section{References}

1. Marangos PJ, Zomzely-Neurath C, Goodwin FK. Structural and functional properties of neuron specific protein (NSP) from rat, cat and human brain. J Neurochem 1977; 28:1097107.

2. Marangos PJ. Neuron specific enolase as a clinical tool. In: Gratzel $M$, Langley $\mathrm{K}$, editors. Neurologic and endocrine disease markers for neural and endocrine cells. New York, Basel, Cambridge, Weinheim: 1990:181-9.

3. Hans P, Bonhomme V, Collette J, Moonen G. Neuron-specific enolase as a marker of in vitro neuronal damage Part I: assessment of neuron-specific enolase as a quantitative and specific marker of neuronal damage. J Neurosurg Anesthesiol 1993; 5:111-6.

4. Marangos PJ, Goodwin FK. Neuron specific protein (NSP) in neuroblastoma cells: relation to differentiation. Brain Res 1978; 145:49-58.

5. Schilling K, Barco EB, Rhinehart D, Pilgrim C. Expression of synaptophysin and neuron-specific enolase during neuronal differentiation in vitro: effects of dimethyl sulfoxide. J Neurosci Res 1989; 24:247-54.

6. Cook JA, Mitchell JB. Viability measurements in mammalian cell systems. Anal Biochem 1989; 179:1-7.

7. Koh JY, Choi DW. Quantitative determination of glutamate mediated cortical neuronal injury in cell culture by lactate dehydrogenase efflux assay. J Neurosci Methods 1987; 20:8390.

8. Andreeva N, Ungethüm U, Heldt J, Gross J. Elevated potassium enhances glutamate vulnerability of dopaminergic neurons developing in mesencephalic cell culture. Exp Neurology. 1996; 137:255-62.

9. Goldberg MP, Weiss JH, Pham PC, Choi DW. N-Methyl-Daspartate receptors mediate hypoxic neuronal injury in cortical culture. J Pharm Exp Ther 1987; 243:784-91.

10. Choi DW. Ionic dependence of glutamate neurotoxicity. $\mathbf{J}$ Neurosci 1987; 7:469-79.

11. Comer AJ, Lees GJ, Lipski J. Neurone-specific enolase persits in some hippocampal cells 24 hours after NMDA injection. Neuroreport 1994; 5:2589-92.

12. Lowry DH, Rosebrough NJ, Farr AL, Randall RJ. Protein measurement with the Folin phenol reagent. J Biol Chem 1951; 193:265-75.

13. Priestley T, Horne AL, McKernan RM, Kemp JA. The effect of NMDA receptor glycine site antagonists on hypoxia-induced neurodegeneration of rat cortical cell cultures. Brain Res 1990; 531:183-8.

14. Schmidt E, Schmidt FW. Enzyme release. J Clin Chem Clin Biochem 1987; 25:525-40.

15. Gross J, Ungethüm U, Moller R, Priem F, Heldt J, Ziebig R, Pawlow I. Präanalytische Faktoren der NSE-Bestimmung im Blut. Lab Med 1995; 19:286-9.

16. Lim L, Hall C, Leung T, Mahadevan L, Whatley S. Neuronespecific enolase and creatine phosphokinase are protein components of rat brain synaptic plasma membranes. J Neurochem 1983; 41:1177-82.

17. Diederichs F, Muhlhaus K, Wittenberg H, Trautschold I. Enzyme release from the perfused rat heart. The functions of the cytoskeleton under cell-pathological conditions. J Clin Chem Clin Biochem 1986; 24:3-9.

18. Lipton SA, Choi YB, Pan ZH, Lei SZ, Chen HSV, Sucher NJ, et al. A redox-based mechanism for the neuroprotective and neurodestructive effects of nitric oxide and related nitrosocompounds. Nature 1993; 364:626-32.

19. Juurlink BHJ, Hertz L. Ischemia-induced death of astrocytes and neurons in primary culture: pitfalls in quantifying neuronal cell death. Dev Brain Res 1993; 71:239-46.

\section{Received October 2, 1995/January 17, 1996}

Corresponding author: Prof. Dr. J. Gross, Universitätsklinikum Charité, Institut für Pathologische und Klinische Biochemie, D-14050 Berlin, Spandauer Damm 130, Germany 